\title{
Nitrogen Fertilization Guidelines for Bare-Ground and Plastic Mulch Cabbage Production in Florida ${ }^{1}$
}

\author{
Lincoln Zotarelli, Charles E. Barrett, Andre Luiz B. R. da Silva, Christian T. Christensen, and Gary \\ K. England ${ }^{2}$
}

\section{Introduction}

This publication focuses on the nitrogen $(\mathrm{N})$ fertilizer best management practices (BMP) for green fresh-market and processing cabbage head (Brassica oleracea Capitata) production in Florida. This publication aims to provide management strategies that comply with statewide BMP guidelines to optimize economic yield while minimizing nitrogen $(\mathrm{N})$ losses to the environment. The guidelines presented in this document are supported by field-based research conducted by UF/IFAS and lay out the foundation for precision agriculture efforts for fresh cabbage production in Florida. This document does not include N-fertilizer guidelines for Chinese cabbage or napa cabbage types. This document is divided into three main sections. The first section describes the cabbage production practices and nutrient demand for different plant development stages. The second section summarizes the research findings for $\mathrm{N}$-fertilizer rate application and timing. The third section provides a practical guide for $\mathrm{N}$-fertilizer management for cabbage in Florida.

In summary, the application of an $\mathrm{N}$-fertilizer rate of 175 $\mathrm{lb} /$ acre may not supply sufficient $\mathrm{N}$ for a cabbage crop when produced on bare ground in sandy soils, primarily due to the excessive $\mathrm{N}$ losses. The information and data presented in this document support adjusting the current UF/IFAS $\mathrm{N}$-fertilizer rate of $175 \mathrm{lb} /$ acre $\mathrm{N}$ for cabbage production to $225 \mathrm{lb} / \mathrm{acre}$ with the adjustment by the plant population for bare-ground and plasticulture systems. These revisions will allow cabbage producers to maintain economically viable yields and sustainable operations across production systems common to the Florida vegetable industry while mitigating water quality impacts associated with overfertilization, improper timing of fertilizer application, and high rainfall events. This publication's target audience is cabbage growers, Extension agents, crop consultants, representatives of the fertilizer industry, state and local agencies, students, instructors, researchers, and interested Florida citizens.

\section{Florida Cabbage Production}

Cabbage is an important vegetable commodity in Florida, planted on approximately 9,000 acres with a value of production of almost $\$ 50$ million (USDA-NASS 2021). Nationally, Florida cabbage ranks 3rd in value of production. Cabbage is produced in several counties across the state, from south Florida (e.g., Palm Beach County) to the Tri-County Agricultural Area (i.e., St. Johns, Flagler, and Putnam Counties). Cabbage is a cool-season crop, and weather during the growing season is a major driver of

1. This document is HS1428, one of a series of the Horticultural Sciences Department, UF/IFAS Extension. Original publication date December 2021. Visit the EDIS website at https://edis.ifas.ufl.edu for the currently supported version of this publication.

2. Lincoln Zotarelli, associate professor, Horticultural Sciences Department; Charles E. Barrett, affiliate professor, Horticultural Sciences Department, and regional specialized agent for water resources; Andre Luiz B. R. da Silva, assistant professor, Department of Horticulture, Auburn University; Christian T. Christensen, Extension center director and regional specialized agent II, UF/IFAS Hastings Agricultural Extension Center, Hastings, FL; Gary K. England, retired Extension center director and regional specialized agent IV, UF/IFAS Hastings Agricultural Extension Center, Hastings, FL; UF/IFAS Extension, Gainesville, FL 32611.

The Institute of Food and Agricultural Sciences (IFAS) is an Equal Opportunity Institution authorized to provide research, educational information and other services

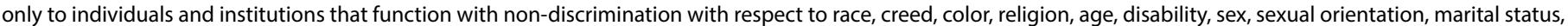

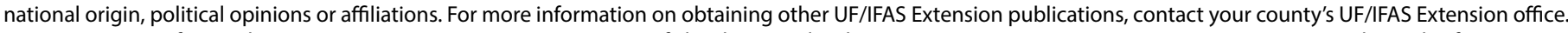
U.S. Department of Agriculture, UF/IFAS Extension Service, University of Florida, IFAS, Florida A \& M University Cooperative Extension Program, and Boards of County Commissioners Cooperating. Nick T. Place, dean for UF/IFAS Extension. 
yield. Thus, differences in yield are expected between years and even planting dates within the same year. For example, the first planting dates around October are characterized by fast initial plant growth, shorter seasons, and higher yield. Planting dates during November coincide with lower air temperature and reduced solar radiation, resulting in a longer season (>100 days) between planting and harvest and relatively lower yield potential.

The majority of the cabbage fields rely on seepage irrigation due to the predominance of production on Spodosols with a shallow water table. There are also cabbage production areas in Florida where the dominant soil types are Entisols with a well-drained soil profile, where sprinkler/overhead irrigation is the predominant irrigation method. For both soil types, cabbage can be produced either on bare ground or plastic mulch with drip irrigation. The commercial production of cabbage under seepage generally uses bare-ground hills spaced 40 inches apart with an in-row plant spacing of 8 inches, which results in approximately 19,600 plants/acre. On well-drained soils, row spacing is generally 36 inches with 8 inches of in-row plant spacing (21,780 plants/acre). In the plasticulture system, cabbage is generally grown on 4 -foot-wide raised beds spaced 6.67 feet center to center, with black plastic mulch and two drip-irrigation tapes. The increased surface area covered by the plastic mulch allows for different plant spacing arrangements (i.e., 3 or 4 planted rows with in-row planting spacing ranging from 10 to 14 inches and a plant population of 16,800 to 26,130 plants/acre) leading to an increase in cabbage plant population per area (Barrett et al. 2015). Despite the $36 \%$ higher cost of plastic mulch and drip systems compared to bare-ground systems, the higher plant population on plasticulture makes the system economically viable, resulting in up to $57 \%$ higher profit than the bareground system (Barrett et al. 2018a; Paranhos et al. 2016). During periods of freezing temperatures, there was far less damage on plasticulture cabbage vs. conventional observed in a demonstration trial in Hastings in the 2018-19 season (Mussoline et al. 2019). The use of plastic mulch and drip tape also includes some benefits regarding $\mathrm{N}$-fertilizer management. With drip irrigation, fertilizer management is facilitated by fertigation, where a nutrient solution, in conjunction with irrigation water, is directly applied to the root zone. Fertilizer applications can be split with ease during the season to match the cabbage nutrient uptake curve (Figure 1). Plastic mulch improves soil water conservation and minimizes the risk of nitrate leaching from the root zone.
The distinctions in plant population between bare-ground and plasticulture systems are very important due to differences in fertilizer amounts per cultivated area; however, we used the amount of fertilizer per plant to compare $\mathrm{N}$ fertilizer rate recommendations between both systems and to perform further adjustments accounting for variations of plant population within each production system.

\section{Summary of $\mathrm{N}$-Fertilizer Research on Cabbage \\ N-Fertilizer Management in Bare-Ground Cabbage Production}

A study was conducted by UF/IFAS to evaluate the cabbage yield and quality in response to $\mathrm{N}$-fertilizer rates in the Hastings, FL area. More details about this study can be found at da Silva et al. (2020). The study was conducted in the winter of 2016 and 2017. The plant population in the study was 19,600 plants/acre, with a plant row spacing of 40 inches center to center and a plant in-row spacing of 8 inches. All fertilizer $\mathrm{N}$ rate treatments received $45 \mathrm{lb} / \mathrm{acre}$ of $\mathrm{N}, 20 \mathrm{lb} / \mathrm{ac}$ of $\mathrm{P}_{2} \mathrm{O}_{5}$, and $37 \mathrm{lb} / \mathrm{acre}$ of $\mathrm{K}_{2} \mathrm{O}$ at preplant of fertilizer blend NPK, and 42, 60, and $78 \mathrm{lb} /$ acre of N (15.5\% $\mathrm{N}$ as calcium nitrate in three subsequent applications for a total of 170,225 , and $280 \mathrm{lb} /$ acre of $\mathrm{N}$ [equivalent to rate of $0.009,0.011$, and $0.014 \mathrm{lb}$ of N per plant, respectively]), applied at 14, 28 and 42 days after transplanting (DAT). Posttransplant fertilizer was banded near the planted row, followed by midrow disking. Cabbage cultivars tested were 'Bravo,' 'Cheers', 'Capture, 'Bronco,' 'Ramada', and 'Bruno'. Two contrasting patterns of rainfall occurred. In 2016, the cumulative rainfall from transplant to harvest was 10.5 inches, with two major rain events of 2.3 and 2.4 inches at 9 and 89 DAT. The 2017 crop season was much drier, with only 2.1 inches and only two occasions with minimum air temperature in the $40 \mathrm{~s}^{\circ} \mathrm{F}$. The average air temperature was similar between both growing seasons, with minimum and maximum average air temperature ranging from $52^{\circ} \mathrm{F}$ to $77^{\circ} \mathrm{F}$. Between 70 and $90 \mathrm{DAT}$ in the 2016 season was also cooler than in 2017, with minimum air temperatures reaching the low $30 \mathrm{~s}^{\circ} \mathrm{F}$ in four occasions.

The lack of interaction between $\mathrm{N}$-fertilizer rates and cabbage cultivars indicated that a similar response of cabbage yield to $\mathrm{N}$-fertilizer rate is expected regardless of cabbage cultivar(s). Cabbage yield response to $\mathrm{N}$-fertilizer was directly related to the precipitation pattern within each season. In 2016, increasing $\mathrm{N}$-fertilizer application rates did not increase total $(45,391 \mathrm{lb} / \mathrm{acre})$ or marketable $(38,618$ $\mathrm{lb} / \mathrm{acre}$ ) cabbage yield (Table 1$)$. In the same year, about $14 \%-16 \%$ of the plants were classified as culls ( $<2 \mathrm{lb}$ heads) 
with no differences between $\mathrm{N}$-fertilizer treatments. The lack of yield response to $\mathrm{N}$-fertilizer rates is an indication that $\mathrm{N}$-fertilizer was not the limiting factor for cabbage yield in 2016. On the contrary, the main reason for reduced yield may be attributed to reduced solar radiation available to the crop in 2016 due to the several days with overcast sky and the low air temperatures during crop maturation.

The growing conditions were more favorable for cabbage production in 2017. Therefore, cabbage yield response to $\mathrm{N}$-fertilizer rates were captured. In 2017, there was an increase in total yield with increasing $\mathrm{N}$-fertilizer rate (Table 1). The $\mathrm{N}$-fertilizer rate of $280 \mathrm{lb} /$ acre yielded more than $170 \mathrm{lb} / \mathrm{acre}$; however, the $225 \mathrm{lb} / \mathrm{acre}$ rate yielded similarly to the 280 and $170 \mathrm{lb} /$ acre rates. Marketable yield was significantly higher in the 225 and $280 \mathrm{lb} /$ acre fertilizer $\mathrm{N}$ rates compared to the $170 \mathrm{lb} / \mathrm{acre} \mathrm{N}$-fertilizer rate. The proportion of culls were $9 \%, 5 \%$, and $4 \%$ for the $\mathrm{N}$-rates 170,225 , and $280 \mathrm{lb} /$ acre of $\mathrm{N}$-fertilizer, respectively. There was no difference in marketable yield for $170 \mathrm{lb} /$ acre of $\mathrm{N}$-fertilizer between 2016 and 2017, confirming that even when growing conditions are favorable as observed in 2017, $170 \mathrm{lb} /$ acre of $\mathrm{N}$-fertilizer rate was not enough to support the potential yield. These results indicates that cabbage yield may be limited with $170 \mathrm{lb} / \mathrm{acre}$ of $\mathrm{N}$ but not with $225 \mathrm{lb} /$ acre of $\mathrm{N}$-fertilizer, which was the fertilizer $\mathrm{N}$ rate required to sustain maximum marketable yields in sandy soils.

\section{N-Fertilizer Management in Plastic Mulch Cabbage Production}

UF/IFAS conducted a series of studies in the Hastings area between 2010 and 2015 to develop crop management practices for cabbage on plastic mulch to optimize cabbage plant population, $\mathrm{N}$-fertilizer rates, and irrigation management (Barrett et al. 2018a, 2018b; Barrett et al. 2015; Paranhos et al. 2016).

A field study conducted in 2013 and 2014 using plastic mulch evaluated cabbage yield and $\mathrm{N}$ uptake of cultivar 'Bronco' for planting dates from September, October, November, and December. The study used a plant population of 26,136 plant/acre (4 rows with plant in-row spacing of 12 inches) and a single $\mathrm{N}$-fertilizer rate of $238 \mathrm{lb} /$ acre of $\mathrm{N}$ (equivalent to $0.009 \mathrm{lb}$ of $\mathrm{N}$ per plant). Preplant granular fertilizer blend was incorporated into the beds using a 10-15-10 (NPK) at a rate of 100, 150, and $100 \mathrm{lb} /$ acre of $\mathrm{N}, \mathrm{P}_{2} \mathrm{O}_{5}$, and $\mathrm{K}_{2} \mathrm{O}$, respectively, prior to fumigation and plastic mulch installation. The preplant fertilizer application supplied $42 \%, 100 \%$, and $42 \%$ of the total $\mathrm{N}, \mathrm{P}_{2} \mathrm{O}_{5}$, and $\mathrm{K}_{2} \mathrm{O}$, respectively. The remaining $\mathrm{N}$ and $\mathrm{K}$ fertilizers were applied by fertigation for a total injected rate of $140 \mathrm{lb} / \mathrm{acre}$ of $\mathrm{N}$ as calcium nitrate ( $15.5 \%$ of $\mathrm{N})$ and $140 \mathrm{lb} /$ acre of $\mathrm{K}_{2} \mathrm{O}$ as muriate potash $\left(61 \%\right.$ of $\left.\mathrm{K}_{2} \mathrm{O}\right)$. Fertigation events were divided into four applications at 14, 28, 42, and 56 DAT. The proportion of $\mathrm{N}$ and $\mathrm{K}_{2} \mathrm{O}$ applied in each fertigation event was equivalent to $8 \%, 15 \%, 20 \%$, and $15 \%$ of the total $\mathrm{N}$ and $\mathrm{K}_{2} \mathrm{O}$. The strategy of splitting fertilizer matched with the cabbage $\mathrm{N}$-uptake curve, and the last application of $\mathrm{N}$ occurred at 56 DAP, which coincided with the peak cabbage $\mathrm{N}$-uptake about 49 DAP (Figure 1).
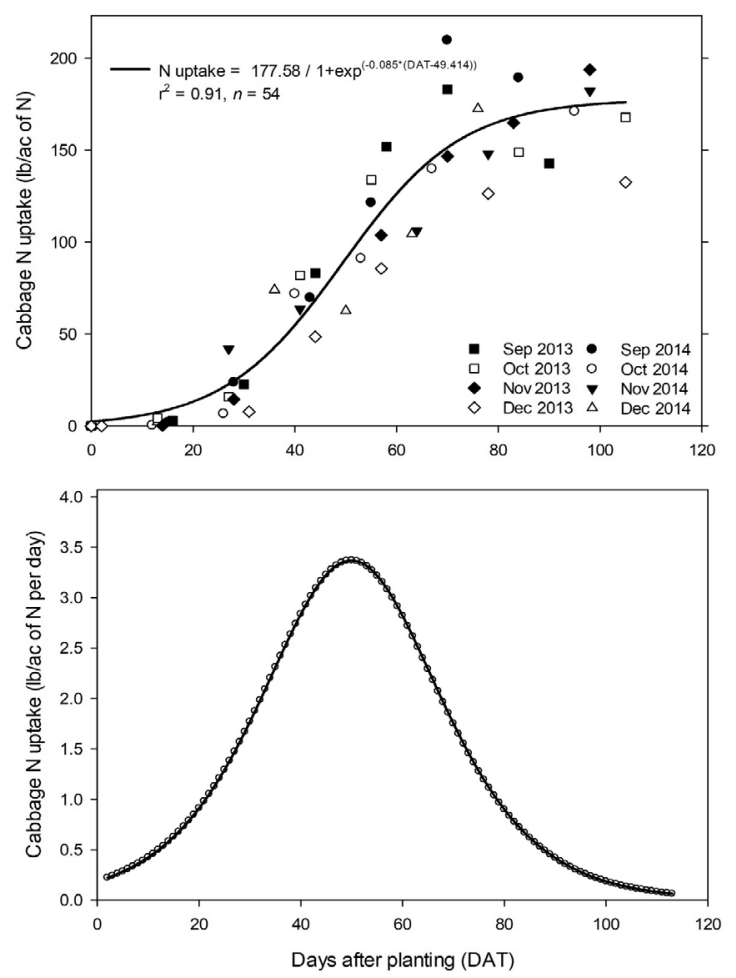

Figure 1. Cabbage aboveground plant $\mathrm{N}$ uptake cultivated on plastic mulch with a plant population of 26,136 plant/acre (upper graph) cultivated in Hastings area for planting dates in September, October, November, and December. Cabbage daily $\mathrm{N}$ uptake rate in Ib/acre of $\mathrm{N}$ per day (lower graph).

Credits: Adapted from Paranhos (2015)

Similarly to other cole crops, cabbage growth is generally slow in the first 20 DAT, corresponding to the seedling developmental stage of up to 9-12 true leaves. In this early stage, plant $\mathrm{N}$ uptake rate increases from 0.25 to $1.0 \mathrm{lb} / \mathrm{acre}$ of $\mathrm{N}$ (Figure 1). Cabbage growth progresses from precupping, head formation, and initial head-filling stages within the period of 30-70 DAT. This period is characterized by a very rapid growth of the aboveground plant tissues and great demand for $\mathrm{N}$ uptake. The measured plant $\mathrm{N}$ uptake rate increased from $1.0 \mathrm{lb} /$ acre of $\mathrm{N} /$ day, peaking around 50 DAT with a rate of $\mathrm{N}$ uptake at $3.5 \mathrm{lb} /$ acre of N/day (Figure 1 , bottom). For cabbage production using fertigation, fertilizer injections should occur between transplant and 70 DAT. The head fill and maturing stages occur after 70-80 
DAT, coinciding with a decrease in the rate of $\mathrm{N}$ uptake up until the time of harvest.

In this study, marketable cabbage yield ranged from 41,853 to $62,809 \mathrm{lb} /$ acre and was mostly impacted by climatic conditions and planting dates. The total $\mathrm{N}$ uptake in the aboveground plant tissues (i.e., cabbage head and wrapper leaves) ranged from approximately 145 to $218 \mathrm{lb}$ /acre of $\mathrm{N}$ across planting dates, which when divided by the plant population in this study is equivalent to 0.006 to $0.008 \mathrm{lb}$ of $\mathrm{N}$ per plant (Table 2). The $\mathrm{N}$ use efficiency (NUE), which is an indicator of capability of the plant to use the soilavailable $\mathrm{N}$, ranged from $27 \%-55 \%$, with an average of $40 \%$.

A $\mathrm{N}$-fertilizer rate study was also conducted using plastic mulch for two consecutive seasons in 2013 and 2014. In the 2013 season, the $\mathrm{N}$-fertilizer rates tested were $80,176,261$, 350 , and $525 \mathrm{lb} /$ acre of $\mathrm{N}$ at a plant population of 31,363 plant/acre (16\% higher population than the previous study). The range of $\mathrm{N}$ applied in the first year was 0.003 to $0.017 \mathrm{lb}$ of N/plant. In the 2014 season, the same plant population was tested and $\mathrm{N}$-fertilizer rates were adjusted to 200, 300, 400,500 , and $600 \mathrm{lb} / \mathrm{acre}$ of $\mathrm{N}$, representing a range of 0.006 to $0.019 \mathrm{lb}$ of N/plant. Preplant granular fertilizer blend was incorporated into the beds using $80 \mathrm{lb} /$ acre of $\mathrm{N}$, $36 \mathrm{lb} / \mathrm{acre}$ of $\mathrm{P}_{2} \mathrm{O}_{5}$, and $66 \mathrm{lb} / \mathrm{acre}$ of $\mathrm{K}_{2} \mathrm{O}$ the 2013 season, and $200 \mathrm{lb} /$ acre of $\mathrm{N}$ rate for the 2014 season. In both seasons, additional $\mathrm{P}$ was supplied preplant using a triple superphosphate 0-20-0 phosphorus fertilizer for a total of $100 \mathrm{lb} /$ acre of $\mathrm{P}_{2} \mathrm{O}_{5}$ for all treatments. Calcium nitrate (15.5-0-0) and potassium chloride (0-0-50) were used to supply the remaining $\mathrm{N}$ and $\mathrm{K}_{2} \mathrm{O}$ via fertigation, keeping $\mathrm{K}$ balanced with $\mathrm{N}$. The fertigation schedule supplied fertilizer at increasing concentrations during the exponential crop growth phase and then at reduced concentrations as crop growth slowed near maturity. During the 2014 season, there were 12 weekly fertigation events in which fertilizer was distributed at $2 \%, 4 \%, 4 \%, 8 \%, 8 \%, 10 \%, 10 \%, 12 \%$, $12 \%, 12 \%, 10 \%$, and $10 \%$ of the injected total, respectively. During the 2014 season, the number of fertigation events was reduced to 7 , in which fertilizer was distributed at $5 \%$, $5 \%, 10 \%, 20 \%, 25 \%, 25 \%$, and $10 \%$ of the injected total, respectively.

Figure 2 shows the cabbage marketable yield response to increasing $\mathrm{N}$-fertilizer rates for the two years of study combined. The 2013 season was much cooler and drier, resulting in higher marketable yield than 2014. Different weather conditions for these cropping seasons allowed for examining cabbage yield in response to $\mathrm{N}$-fertilizer rates and a determination of an optimum $\mathrm{N}$ application rate range regardless of the weather conditions. Maximum cabbage marketable yield as indicated by the response of a quadratic-plateau model was reached with $\mathrm{N}$-fertilizer rates of $355 \mathrm{lb} /$ acre (equivalent to $0.0113 \mathrm{lb}$ of N/plant) and no additional increase in yield with $\mathrm{N}$-fertilizer rates above 355 $\mathrm{lb} / \mathrm{ac}$.
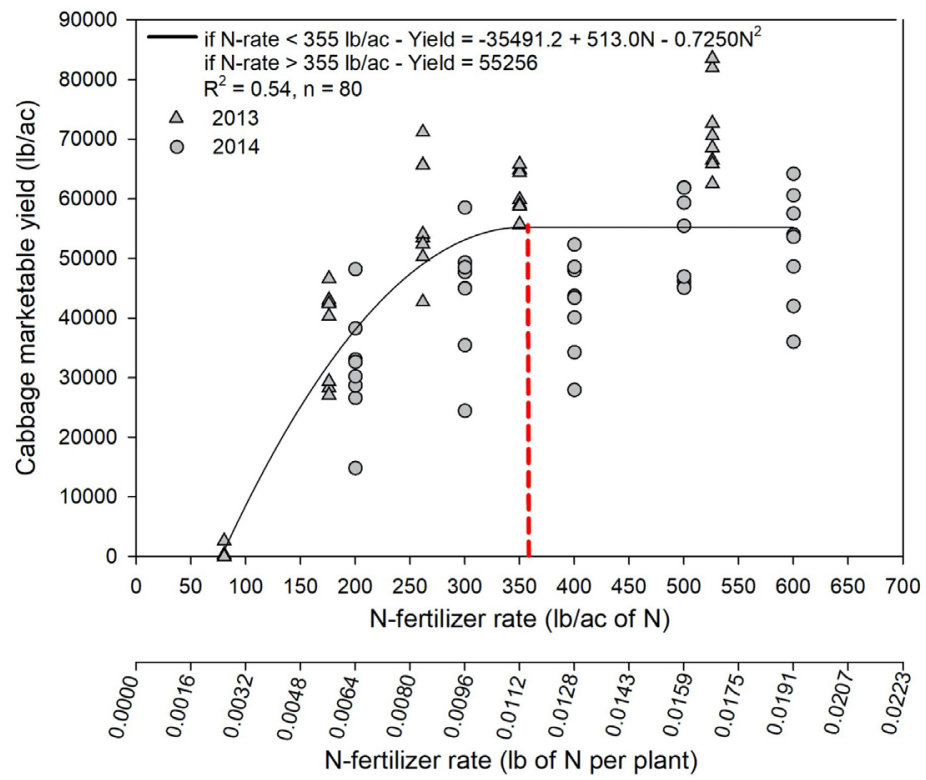

Figure 2. Cabbage marketable yield response to $\mathrm{N}$-fertilizer rates ( $\mathrm{N}$-fertilizer rates expressed in $\mathrm{lb} / \mathrm{acre}$ and $\mathrm{lb} /$ plant adjusted by plant population) for cultivar 'Bravo' grown on plastic mulch with a plant population of 31,363 plants/acre in Hastings, FL in 2013 and 2014. The red dotted line indicates maximum marketable yield estimated by setting the first derivative of the quadratic equation generated by the regression analysis equal to zero. The total number of observations = 80.

Credits: Data source: Barrett et al. (2018b)

The results from the plastic mulch trials are comparable to the bare-ground trials when the rates are expressed on a plant population basis, indicating that a minimum $\mathrm{N}$-fertilizer rate of $0.0115 \mathrm{lb}$ of $\mathrm{N} /$ plant is required, and the per-plant rate can be adjusted to a rate per acre using the actual plant population. For example, bare-ground cabbage production with 19,600 plants/acre would require a Nfertilizer rate of $225 \mathrm{lb} /$ acre of $\mathrm{N}$, while cabbage cultivated on plastic mulch with a plant population of 26,136 plant/ acre would require a $\mathrm{N}$-fertilizer rate of $300 \mathrm{lb} /$ acre of $\mathrm{N}$ to achieve maximum yield. It is noteworthy that the bareground system is a less efficient system with regard to use of space, irrigation water use, and susceptibility to nutrient loss via leaching than the plastic mulch system. In bare ground, supplemental $\mathrm{N}$-fertilizer rate may be required if excessive rainfall occurs after the last fertilizer application. In this case, guidelines for supplemental application can be found in EDIS article HS711, "Soil and Fertilizer Management for Vegetable Production in Florida" (https://edis.ifas. ufl.edu/cv101). Application of supplemental N-fertilizer using plasticulture and fertigation should be carefully 
evaluated because the susceptibility of leaching is much reduced compared to the bare-ground system.

\section{$\mathrm{N}$-Fertilizer Best Management Practices for Cabbage}

Best management practices are defined as a practice or combination of practices based on research, field-testing, and expert review to the most effective and practical on-location means, including economic and technological considerations for improving water quality in agricultural discharges (FDACS 2015). Many factors that should be considered to design an $\mathrm{N}$-fertilizer program for cabbage are based on the "Four Rs Principles," which include the right rate, right timing of application, right placement, and right source of fertilizer and in-season diagnostic of nutrient status. More information on the general concepts of 4 Rs can be found at EDIS article SL411, "The Four Rs of Fertilizer Management" (https://edis.ifas.ufl.edu/ss624). The principles of plant nutrition presented in the BMP manual (FDACS 2015) are discussed below, emphasizing cabbage.

\section{PRINCIPLE 1-SUPPLYING THE RIGHT AMOUNT OF NUTRIENTS BASED ON PLANT POPULATION, CULTIVATION METHOD, AND PLANTING DATE}

The selection of a realistic $\mathrm{N}$-fertilizer rate for cabbage is an important decision that will directly impact yield, economic return, and potential $\mathrm{N}$ leaching. It is noteworthy that the $\mathrm{N}$-fertilizer rate is not the only factor that can limit cabbage yield. Other factors impacting cabbage yield potential include, but are not limited to, planting date, cultivars, soil type, weather conditions, disease and pest management, and adequate irrigation. A commercial cabbage head size ranges between $2-4 \mathrm{lb}$; oversized heads $>4 \mathrm{lb}$ are not desirable and frequently refused by fresh produce buyers. Cabbage yield is limited to one head per plant, so increasing the plant population per acre is one way to increase the yield per area, and excessive $\mathrm{N}$-fertilizer applications will not increase yield. Because there is a limit on commercial cabbage head size, assuring that the required amount of $\mathrm{N}$ is available for plant uptake when needed is critical for a successful nutrient management plan. UF/IFAS has determined that a cabbage plant will require about 0.0115 $\mathrm{lb}$ of $\mathrm{N}$-fertilizer/plant. This value was determined using two independent methods:

(1) By determining the total amount of $\mathrm{N}$ in the aboveground plant tissues, which ranged from 145 to $218 \mathrm{lb} / \mathrm{acre}$, then dividing by the number of plants in the study, which resulted in 0.006 to $0.008 \mathrm{lb}$ of $\mathrm{N}$ per plant. The average
NUE was $40 \%$, meaning $40 \%$ of the $\mathrm{N}$-fertilizer applied was used by the cabbage plant. Using these N-per-plant and NUE values, the $\mathrm{N}$-fertilizer rate required ranges from 0.096 to $0.0128 \mathrm{lb}$ of $\mathrm{N}$-fertilizer per plant.

(2) By using the $\mathrm{N}$-fertilizer rate curve (Figure 2), from which a maximum yield of 55,256 lb/acre was obtained when $\mathrm{N}$-fertilizer rate reached $355 \mathrm{lb} /$ acre (or $0.0113 \mathrm{lb}$ of N/plant) for a population of 31,363 plant/ac. From the bare-ground study, it was concluded that the minimum $\mathrm{N}$-fertilizer rate of $225 \mathrm{lb} /$ acre $(0.0114 \mathrm{lb}$ of N/plant) was necessary to reach the average cabbage yield $55,777 \mathrm{lb} / \mathrm{ac}$.

In practice, the $\mathrm{N}$-fertilizer for cabbage can be determined as follows:

Example 1: Cabbage grown on bare ground with a row spacing of 36 inches with in-row plant spacing of 8 inches has a population of 21,780 plants/acre $\times 0.0115 \mathrm{lb}$ of N/ plant $=250 \mathrm{lb} /$ acre of $\mathrm{N}$-fertilizer.

Example 2: Cabbage grown on plastic mulch 4-foot-wide raised beds spaced 6.6 feet center to center with black plastic mulch and two drip-irrigation tapes. Plant arrangement is 3 planted rows with in-row spacing of 10 inches, with a total plant population of 23,522 plants/acre. Plant population of 23,522 plants/acre $\times 0.0115 \mathrm{lb}$ of N/plant $=$ $271 \mathrm{lb} /$ acre of $\mathrm{N}$-fertilizer.

Table 3 and 4 present equivalent $\mathrm{N}$-fertilizer rate recommendation according to variations of plant population based on row spacing and in-row plant spacing for bareground and plastic mulch cabbage production in Florida.

\section{PRINCIPLE 2-DIMINISHING RETURNS}

Increasing $\mathrm{N}$-fertilizer rates showed a positive response to marketable cabbage yield up to a $\mathrm{N}$-fertilizer rate of 225 $\mathrm{lb} /$ acre of $\mathrm{N}(0.0115 \mathrm{lb} /$ plant $)$ on bare ground and $335 \mathrm{lb} /$ acre $(0.0113 \mathrm{lb} /$ plant $)$ on high-population plastic mulch. At $\mathrm{N}$-fertilizer rates above that point, marketable yield stops responding to increasing $\mathrm{N}$-fertilizer applications; reductions in net return may occur with the increase cost of $\mathrm{N}$-fertilizer.

\section{PRINCIPLE 3-FERTILIZER TIMING}

$\mathrm{N}$-fertilizer application timing can effectively reduce $\mathrm{N}$-fertilizer leaching in cabbage production because of the improved synchronization with crop demand. The optimum application timing of $\mathrm{N}$-fertilizer for cabbage should match the nutrient uptake curve (Figure 1). In practice, three to four split applications should be considered. For bare ground, application of $20 \%-30 \%$ of the $\mathrm{N}$ can be 
incorporated in the row or bed at planting, followed by two additional applications (e.g., at 6-8 inch tall plants and the initial head formation stage) as top-dress, banded, or knifed-in on the side of rows with liquid fertilizer.

Additional N-fertilizer applications can occur after leaching rain events. Guidelines for supplemental application can be found at EDIS article HS711, "Soil and Fertilizer Management for Vegetable Production in Florida" (https://edis.ifas. ufl.edu/cv101).

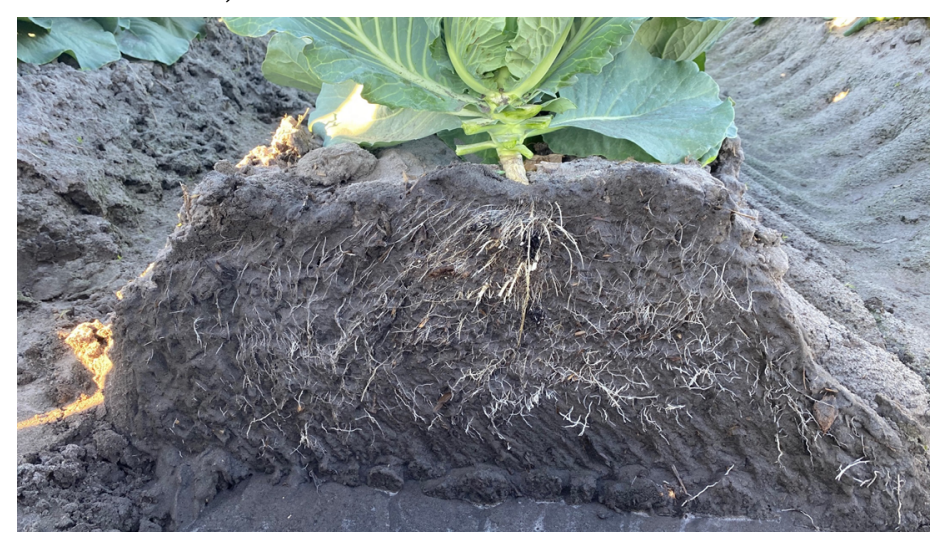

Figure 3. Root distribution of cabbage cultivated on bare ground (40-inch row spacing with in-row plant spacing of 8 inches, 19,600 plants/acre). Placement of fertilizer should target areas with high concentration of roots, avoiding broadcast application of fertilizer. Credits: L. Zotarelli, UF/IFAS

For the drip-irrigated, plastic mulch systems, apply $30 \%$ of $\mathrm{N}$-fertilizer in the bed at planting. The remaining $\mathrm{N}$ fertilizer can be injected up to 4 times during the season every two weeks (e.g., 14, 28, 42, and 56 DAT) at equivalent rates of $10 \%, 15 \%, 25 \%$, and $20 \%$ of the total N.

In-season adjustment of $\mathrm{N}$-fertilizer can be made by evaluating the plant tissue $\mathrm{N}$ concentration (i.e., dry samples sent to the lab for total $\mathrm{N}$ content analysis; results are generally expressed as percentages). In this case, the most recently mature leaf can be sampled 8 weeks after planting. The adequate level of N\% concentration is between 3\%-6\%; N\% concentration below and above these values indicates high and deficient levels of N\% concentration, respectively.

\section{PRINCIPLE 4-FERTILIZER SOURCES}

$\mathrm{N}$-fertilizer sources can be found in ammoniacal and nitrate forms. In the soil, nitrate forms are preferred by plants for uptake, but they are also more susceptible to leaching than ammonium. Thus, in selecting $\mathrm{N}$-fertilizer sources, it is recommended that $25 \%-50 \%$ of the $\mathrm{N}$-fertilizer be supplied from nitrate sources (Liu et al. 2018). Also, the application of $\mathrm{N}$-fertilizers in liquid or dry form has not shown differences in yield response. Guidelines on the conversion from liquid to dry and vice-versa can be found in EDIS article HS1200, "How to Convert Liquid Fertilizer into Dry
Fertilizer in Fertigation for Commercial Vegetable and Fruit Crop Production" (https://edis.ifas.ufl.edu/hs1200).

A successful $\mathrm{N}$-fertilization program can be achieved using water-soluble $\mathrm{N}$-fertilizer sources when the proper timing and rate of $\mathrm{N}$-fertilizer are chosen. The use of controlledrelease $\mathrm{N}$-fertilizers (CRF) or slow-release fertilizer (SLF) is not widely adopted by cabbage growers, mainly because of the higher relative cost compared to the water-soluble sources and the uncertainties in synchronization of nutrient release and plant uptake. More research is needed to match the synchronization of CRF $\mathrm{N}$-fertilizer sources for shortseason vegetable crops like cabbage. More information on the use of CRF can be found in EDIS article HS1255 "Controlled-Release and Slow-Release Fertilizers as Nutrient Management Tools” (https://edis.ifas.ufl.edu/hs1255).

\section{References}

Barrett, C. E., L. Zotarelli, L. G. Paranhos, P. Dittmar, C. W. Fraisse, and J. VanSickle. 2018a. "Economic Feasibility of Converting from a Bare Ground System with Seepage Irrigation to Plasticulture for Cabbage Production: Where Is the Risk?" HortScience 53 (6): 875-881. https://doi. org/10.21273/HORTSCI12966-18

Barrett, C. E., L. Zotarelli, L. G. Paranhos, P. Dittmar, C. W. Fraisse, and J. VanSickle. 2018b. "Optimization of Irrigation and N-Fertilizer Strategies for Cabbage Plasticulture System." Scientia Horticulturae 234:323-334. https://doi. org/10.1016/j.scienta.2018.02.063

Barrett, C. E., L. Zotarelli, L. G. Paranhos, B. S. Taylor, P. Dittmar, C. W. Fraisse, and J. VanSickle. 2015. “Optimum Planting Configuration for High Population Plasticulture Grown Cabbage." HortScience 50 (10): 1472-1478. https:// doi.org/10.21273/HORTSCI.50.10.1472

da Silva, A. L. B. R., J. S. Candian, L. Zotarelli, T. Coolong, and C. T. Christensen. 2020. "Nitrogen Fertilizer Management and Cultivar Selection for Cabbage Production in the Southeastern United States." HortTechnology 30 (6): 685-691. https://doi.org/10.21273/HORTTECH04690-20

Mussoline, W., B. Wells, G. K. England, and L. Zotarelli. 2019. "Improved Productivity and Economic Advantages of Advanced Cabbage Production on Plasticulture." Proc. of Fla. State Hort. 132:108-110. http://fshs.org/wp-content/ uploads/2021/03/2019-full_reduced_size.pdf 
Paranhos, L. G. 2015. "High Density Cabbage Production under Plasticulture: Yield, Nitrogen Uptake, Irrigation Demand and Economics." Horticultural Sciences. University of Florida, Gainesville, FL, p. 115.

Paranhos, L. G., C. E. Barrett, L. Zotarelli, T. Borisova, R. Darnell, and K. Migliaccio. 2016. "Cost-Benefit Analysis of Cabbage Grown Using a Plasticulture and seepage bare ground Production System in Florida." Hort-

Technology 26 (6): 699-706. https://doi.org/10.21273/ HORTTECH03444-16

USDA-NASS. 2021. "2020 State Agriculture Overview - Florida." Acessed 12 April 2021. https://www.nass. usda.gov/Quick_Stats/Ag_Overview/stateOverview. php?state=FLORIDA 
Table 1. Cabbage total and marketable yield (head size $>2 \mathrm{lb}$ ) response to $\mathrm{N}$-fertilizer rates under bare-ground production system with 19,600 plants/acre in Florida. Adapted from da Silva et al. (2020).

\begin{tabular}{|c|c|c|c|c|c|}
\hline \multirow[b]{2}{*}{$\mathrm{N}$-fertilizer rate } & \multicolumn{3}{|c|}{ Year } & & \multirow[b]{2}{*}{2016 vs $2017^{x}$} \\
\hline & \multicolumn{2}{|c|}{2016} & \multicolumn{2}{|c|}{2017} & \\
\hline Ib/acre (Ib/plant) & \multicolumn{5}{|c|}{ Ib/acre } \\
\hline \multicolumn{6}{|l|}{ Total yield } \\
\hline 170 (0.0087 lb/plant) & 45,434 & $A^{\dagger}$ & 47,929 & $\mathrm{~B}^{+}$ & $* \neq$ \\
\hline 225 (0.0115 lb/plant) & 46,587 & $A$ & 51,865 & $A B$ & * \\
\hline 280 (0.0143 lb/plant) & 44,152 & $A$ & 54,564 & $A$ & * \\
\hline \multicolumn{6}{|l|}{ Marketable yield } \\
\hline 170 (0.0087 lb/plant) & 38,705 & $A$ & 43,710 & B & $\mathrm{ns}^{\ddagger}$ \\
\hline 225 (0.0115 lb/plant) & 39,935 & $A$ & 49,335 & $A$ & * \\
\hline 280 (0.0143 lb/plant) & 37,214 & $A$ & 52,219 & $A$ & * \\
\hline \multicolumn{6}{|c|}{$\begin{array}{l}{ }^{\dagger} \text { Mean total or marketable yield values followed by the same uppercase letter within year (column) indicates no significant differences ( } p \leq \\
0.05 \text { ) among fertilizer N rate (row) according to Tukey-Kramer adjustment. } \\
{ }^{\ddagger} \text { ns indicates no significant differences }(p \leq 0.05) \text { in yield between } 2016 \text { and } 2017 \text { within each N-fertilizer rate according to Tukey-Kramer } \\
\text { adjustment. }\end{array}$} \\
\hline
\end{tabular}

Table 2. Marketable yield (lb/acre), aboveground $\mathrm{N}$ accumulation (lb/acre), and nitrogen use efficiency (NUE) for cabbage cultivar 'Bronco' fertilized with $238 \mathrm{lb} /$ acre of $\mathrm{N}$ (i.e., equivalent to $0.009 \mathrm{lb}$ of $\mathrm{N}$ per plant) and a plant population of 26,136 plant/acre cultivated on plastic mulch in the 2013 and 2014 seasons in Hastings, FL. Adapted from Paranhos (2015).

\begin{tabular}{|l|c|c|c|c|c|c|}
\hline & \multicolumn{2}{|c|}{$\begin{array}{c}\text { Marketable Yield } \\
\text { (lb/acre) }\end{array}$} & \multicolumn{2}{c|}{$\begin{array}{c}\text { Aboveground N Accumulation (Ib/ } \\
\text { acre of N) }\end{array}$} & \multicolumn{2}{c|}{$\begin{array}{c}\text { Nitrogen Use Efficiency } \\
\text { (\%) }\end{array}$} \\
\hline Planting Date & $\mathbf{2 0 1 3}$ & $\mathbf{2 0 1 4}$ & $\mathbf{2 0 1 3}$ & $\mathbf{2 0 1 4}$ & $\mathbf{2 0 1 3}$ \\
\hline SEP & $50,675 \mathrm{~b}^{\dagger}$ & $61,203 \mathrm{a}$ & $133 \mathrm{~b}$ & $166 \mathrm{~b}$ & $34 \mathrm{~b}$ & $42 \mathrm{~b}$ \\
\hline OCT & $57,902 \mathrm{a}$ & $50,051 \mathrm{~b}$ & $154 \mathrm{~b}$ & $146 \mathrm{~b}$ & $39 \mathrm{~b}$ & $37 \mathrm{~b}$ \\
\hline NOV & $44,707 \mathrm{c}$ & $37,560 \mathrm{c}$ & $181 \mathrm{a}$ & $170 \mathrm{~b}$ & $46 \mathrm{a}$ \\
\hline DEC & $41,843 \mathrm{c}$ & $62,809 \mathrm{a}$ & $106 \mathrm{c}$ & $218 \mathrm{a}$ & $27 \mathrm{c}$ & $43 \mathrm{~b}$ \\
\hline
\end{tabular}

${ }^{+}$Values followed by the same lowercase letter within 2013 and 2014 seasons indicate that marketable yield, N accumulation, and N use efficiency was not significantly different $(P \leq 0.05)$ with mean separation by Tukey-Kramer test. The nitrogen use efficiency (NUE) was calculated dividing the total $\mathrm{N}$-uptake by the plant by the total amount of nitrogen supplied via fertilization plus the initial soil $\mathrm{NO}_{3}-\mathrm{N}$. 
Table 3. Cabbage plant population (plants per acre) as function of row spacing and in-row plant spacing and respective $\mathrm{N}$-fertilizer rate recommendations for cabbage grown on bare ground in Florida.

\begin{tabular}{|c|c|c|c|c|c|c|c|c|}
\hline \multirow[b]{2}{*}{ In-Row Plant Spacing } & \multicolumn{4}{|c|}{$\begin{array}{l}\text { Plant Population (plants/acre) by Row Spacing } \\
\text { (inches) }\end{array}$} & \multicolumn{4}{|c|}{ N-Fertilizer Rate by Row Spacing (inches) } \\
\hline & 24 & 30 & 36 & 40 & 24 & 30 & 36 & 40 \\
\hline 8 inches & 32,670 & 26,136 & 21,780 & 19,602 & 376 & 301 & 250 & 225 \\
\hline 10 inches & 26,136 & 20,909 & 17,424 & 15,682 & 301 & 240 & 200 & 180 \\
\hline 12 inches & 21,780 & 17,424 & 14,520 & 13,068 & 250 & 200 & 167 & 150 \\
\hline
\end{tabular}

Table 4. Cabbage plant population (plants per acre) as function of bed spacing, number of cultivated rows per bed, and in-row plant spacing and respective $\mathrm{N}$-fertilizer rate recommendations for cabbage grown on plastic mulch in Florida.

\begin{tabular}{|c|c|c|c|c|}
\hline \multirow[b]{3}{*}{ In-Row Plant Spacing } & \multicolumn{4}{|c|}{ Plant Population (plants/acre) } \\
\hline & \multicolumn{2}{|c|}{ 6-Foot Bed Spacing (3-Foot Bed Width) } & \multicolumn{2}{|c|}{ 6.67-Foot Bed Spacing (4-Foot Bed Width) } \\
\hline & 2 rows & 3 rows & 3 rows & 4 rows \\
\hline 8 inches & 21,780 & 32,670 & 29,403 & 39,204 \\
\hline 10 inches & 17,424 & 26,136 & 23,522 & 31,363 \\
\hline 12 inches & 14,520 & 21,780 & 19,602 & 26,136 \\
\hline \multirow[t]{2}{*}{14 inches } & 12,446 & 18,669 & 16,802 & 22,402 \\
\hline & \multicolumn{4}{|c|}{ N-Fertilizer Rate (lb/acre) } \\
\hline 8 inches & 250 & 376 & 338 & 451 \\
\hline 10 inches & 200 & 301 & 271 & 361 \\
\hline 12 inches & 167 & 250 & 225 & 301 \\
\hline 14 inches & 143 & 215 & 193 & 258 \\
\hline
\end{tabular}

